\title{
Verschuivingen in informatievoorziening tijdens Covid-19
}

\section{Gevolgen voor vertrouwen en democratische processen}

\author{
Rens Vliegenthart, Bert N. Bakker \& Claes de Vreese*
}

Een pandemie vraagt om sterke reacties van de uitvoerende macht. In het geval van Covid-19 heeft dit in 2020 geleid tot het verbieden van bijeenkomsten in de publieke ruimte en het beperken van de bewegingsvrijheid. Maar ook institutionele democratische processen kwamen onder druk en soms tot stilstand. De Tweede Kamer mocht niet meer fysiek bijeenkomen. Gemeenteraden stelden vergaderingen uit. Burgemeesters en wethouders namen ingrijpende besluiten verpakt in noodverordeningen. Deze en andere maatregelen dienen een duidelijk doel: het indammen van het virus. Over het algemeen lijkt er veel steun te zijn voor deze maatregelen (Jørgensen e.a., 2020). Toch verschilt de implementatie van deze maatregelen substantieel tussen landen. Het lijkt erop dat landen met een meer autoritair verleden ook strengere beperkingen op de democratische vrijheden van burgers doorvoerden tijdens de coronacrisis (Trein, 2020).

De vraag is in hoeverre de coronacrisis de percepties van burgers over de democratie heeft beïnvloed. Onderzoek uit Nederland laat zien dat in vergelijking met 2017 Nederlanders in mei 2020 zich meer zorgen maakten over de inbreuk op hun privacy door de overheid (Reeskens e.a., 2020). Nederlanders lijken sceptisch over het gebruik van 'contact tracing' door de overheid om de pandemie te bestrijden. In experimenten in de Verenigde Staten en het Verenigd Koninkrijk vonden Arceneaux e.a. (2020) dat deelnemers aan de studie vrij veel democratische vrijheden op wilden geven om de coronacrisis te bestrijden. Vragenlijstonderzoek in vijftien landen - Australië, Canada, China, Duitsland, Frankrijk, India, Italië, Japan, Nederland, Singapore, Spanje, Verenigd Koninkrijk, Verenigde Staten, Zuid-Korea en Zweden - door Alsan en collega's (2020) liet zien dat in alle landen deelnemers aan de studie hun democratische vrijheden wilden inruilen om het coronavirus te bestrijden.

Wat we niet weten is in hoeverre informatievoorziening een positief of negatief effect heeft gehad op de opvattingen over de democratie. De informatie die mensen via traditionele en sociale media tot zich nemen, heeft een belangrijke invloed op wat zij weten over maatschappelijke onderwerpen en wat zij daarvan vinden. Dat zal zeker in het geval van de hoogst onzekere crisiscontext die Covid-19 creëerde het geval zijn geweest. In deze studie onderzoeken we de vol-

* Prof. dr. Rens Vliegenthart is hoogleraar media en samenleving en wetenschappelijk directeur van de Amsterdam School of Communication Research. Dr. Bert N. Bakker is assistant professor aan de Amsterdam School of Communication Research. Prof. dr. Cleas de Vreese is professor political communication aan de Amsterdam School of Communication Research. 
gende twee vragen: (1) We onderzoeken in hoeverre verschuivingen in de informatievoorziening tijdens Covid-19 samenhangen met de relatie met vertrouwen in de lokale/nationale overheid. (2) Daarnaast onderzoeken we in hoeverre verschuivingen in de informatievoorziening tijdens Covid-19 samenhangen met het beeld van de democratische processen die onder druk staan.

\section{Methode}

Voor deze studie baseren wij ons op een surveyonderzoek dat gedaan is door het onderzoeksbureau I\&O Research in opdracht van de Amsterdam School of Communication Research (ASCoR) aan de Universiteit van Amsterdam (zie Bakker, Van der Wal \& Vliegenthart, 2020). In de periode april-september is dezelfde groep respondenten vijf keer een vragenlijst voorgelegd. Vanaf de tweede keer (golf) zijn daarbij ook vragen rond democratie en participatie gesteld. De eerste golf vond plaats op 10 april 2020 en werd uitgezonden naar 3750 potentiële respondenten, opnieuw gestratificeerd naar geslacht, leeftijd, regio en opleidingsniveau. Hiervan hebben 1742 respondenten de enquête vóór 20 april ingevuld (responspercentage $=49,8$ ). De tweede golf was in het veld tussen 30 april en 11 mei en leverde 1423 reacties op (retentiepercentage $=81,7$ ). De derde golf (25 mei tot 3 juni) leverde 1241 reacties op (retentiepercentage $=87,2$ ). De vierde golf was in het veld tussen 29 juni en 7 juli met een retentiepercentage van 87,3 $(\mathrm{N}=1084)$. De laatste golf werd gehouden na de zomer, tussen 11 en 16 september (retentiepercentage van 83,3). In totaal vulden 898 respondenten alle vier de enquêtes in die we in onze analyses gebruiken. Het ministerie van Binnenlandse Zaken en Koninkrijkrelaties heeft een aantal vragen over informatiepatronen en percepties van democratische processen mogelijk gemaakt.

Onze belangrijkste onafhankelijke variabele is mediagebruik. Deze wordt vastgesteld aan de hand van de vraag hoe vaak respondenten per week een hele reeks aan media gebruikten en specifieke televisieprogramma's keken. Op basis van een factoranalyse worden vijf vormen van nieuwsgebruik geïdentificeerd: publiek televisiegebruik (met name NOS-journaal en talkshows), commercieel televisiegebruik (RTL-nieuws en talkshow Beau/Jinek), krantengebruik (zowel landelijke als regionale kranten), socialemediagebruik (inclusief WhatsApp) en het gebruik van expertsites zoals rivm.nl en thuisarts.nl. Voor elke vorm van nieuwsgebruik berekenen we het gemiddelde van het aantal keren per week dat respondenten de media/programma's binnen de betreffende categorie consumeerden.

Als afhankelijke variabelen gebruiken we een aantal vragen die politieke percepties en attitudes meten. Ten eerste politiek vertrouwen. Hierbij vragen we op een schaal van 1 (helemaal geen vertrouwen) tot 7 (veel vertrouwen) hoeveel vertrouwen de respondent heeft in de regering en de lokale overheid.

Ten tweede democratische percepties: hierbij kijken we naar de mate waarin respondenten het eens zijn met de volgende stellingen zolang de coronacrisis duurt:

1 Staan lokale democratische processen onder druk? 
2 Staan nationale democratische processen onder druk?

3 Moeten burgemeesters en wethouders beslissingen kunnen nemen zonder dat de gemeenteraad daarover hoeft mee te beslissen?

4 Moeten gemeenteraadsverkiezingen en referenda tot nader orde worden uitgesteld?

5 Mogen burgers niet inspreken bij de gemeenteraadsvergaderingen?

Wederom gebruiken we een schaal van 1 (helemaal mee oneens) tot 7 (helemaal mee eens). Daarnaast nemen we het gemiddelde van de eerste twee als afhankelijke variabele ervaren democratische druk en de laatste drie als steun voor democratiebeperkende maatregelen.

De laatste set afhankelijke variabelen die we bekijken, richten zich op participatie in de brede zin. Hierbij kijken we in hoeverre mensen online Kamerdebatten, persconferenties van Rutte en online gemeenteraadsdebatten volgen. Hier gebruiken we een schaal van 0 (nooit) tot 4 (altijd).

In een aantal van onze analyses maken we gebruik van controlevariabelen: leeftijdsgroep (drie oplopende categorieën, van 18-34 tot 65+), opleidingsniveau (drie oplopende categorieën, van laag naar midden en hoog) en geslacht.

Voor de analyses gebruiken we multivariate regressieanalyses met de waarde van de afhankelijke variabele van de vorige wave ('lagged') als onafhankelijke variabele. Verder zijn de standaardfouten geclusterd binnen respondenten, om zo rekening te houden met het feit dat dezelfde respondent meerdere keren in de analyse voorkomt. Ten slotte voegen we dummy-variabelen toe voor de verschillende waves, zodat we algemene overtijdverschillen door de afnemende ernst van de crisis niet toeschrijven aan veranderend mediagebruik.

\section{Resultaten}

Allereerst kijken we naar het (veranderende) mediagebruik in de verschillende categorieën die we onderscheiden (figuur 1). De absolute waarden zijn moeilijk te vergelijken, omdat de categorieën een reeks aan heel verschillende onderliggende media/programma's hebben, maar wat wel opvalt is de kleine maar gestage afname van het gebruik in vier van de vijf gevallen door de tijd heen. Vergelijkingen van gemiddelden (t-testen) laten zien dat de afname in mediagebruik tussen de eerste en tweede golf significant is voor alle media. Daarnaast vinden we verderop in de tijd nog enige significante afnames, maar die zijn minder groot. Dit maakt duidelijk dat mediagebruik aan het begin van de coronacrisis, misschien weinig verrassend, erg hoog was, maar dat de informatiebehoefte wel enigszins terugliep naarmate de situatie verbeterde. Relatief gezien loopt met name het gebruik van expertsites sterk terug. De enige uitzondering is het gebruik van de NPO-programma's (publieke omroep), waarbij geen duidelijke trend waarneembaar is. Mensen kijken naar de NPO of niet. Het gebruik van sociale media (inclu- 


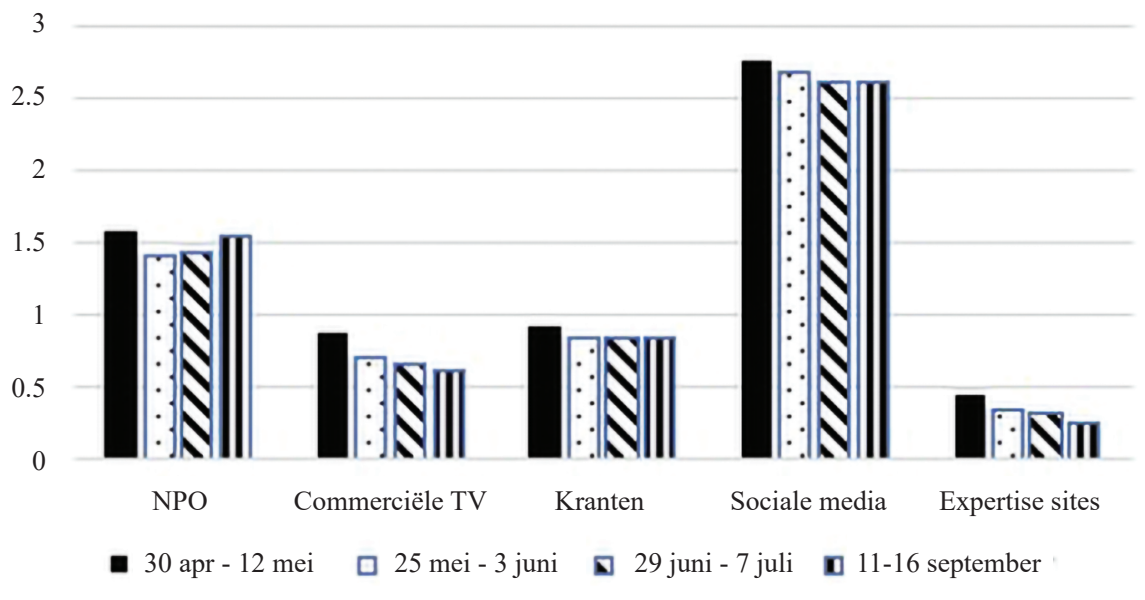

Figuur 1 Mediagebruik. De y-as geeft het gemiddelde van het aantal keren (dagen) per week dat respondenten de media/programma's binnen de betreffende categorie consumeerden.

sief WhatsApp), die niet specifiek voor nieuws gebruikt worden, vertoont een vergelijkbare trend als de andere mediatypes.

Figuur 2 laat het politieke vertrouwen in de regering en lokale overheid zien. In beide gevallen vinden we een dalende lijn, alhoewel de verschillen voor de lokale overheid in veel gevallen niet significant zijn. Was het vertrouwen eind april/ begin mei nog rond de 4,5 (op een 7-puntsschaal) voor de regering en iets boven de 4 voor de lokale overheid, in september was dat voor beide onder de 4 . Met name het vertrouwen in de regering loopt stevig terug en deze afname is tussen alle opvolgende waves significant. Ook dit is een opvallende uitkomst, maar misschien niet geheel onverwachts. We weten dat in het begin van een crisis de steun voor autoriteiten hoog is ('rally around the flag') en dat deze vaak terugloopt als de crisis aanhoudt. Eerste studies rond de coronacrisis laten zien dat gedurende de eerste golf burgers meer steun voor zittende politici hadden (Bol e.a., 2020; Baekgaard e.a., 2020; De Vries e.a., 2020; Giommoni \& Loumeau, 2020).

Onder Nederlanders is het gevoel dat de coronacrisis de nationale en lokale democratie onder druk zet duidelijk aanwezig, en deze gevoelens nemen gedurende de onderzoeksperiode maar zeer beperkt af. Voor beide geldt dat de scores op bijbehorende vragen in alle metingen ergens tussen de 4 en 4,5 liggen (op een 7puntsschaal). Meer variatie vinden we in de meningen over democratiebeperkende maatregelen. De steun hiervoor is redelijk beperkt en iets afnemend. Uitzondering is de mening over het mogelijk uitstellen van gemeenteraadverkiezingen en referenda. Aanvankelijk voelen mensen daar wel voor (score van rond de 4,5), maar die steun loopt snel terug naar een score van 3 in september. 


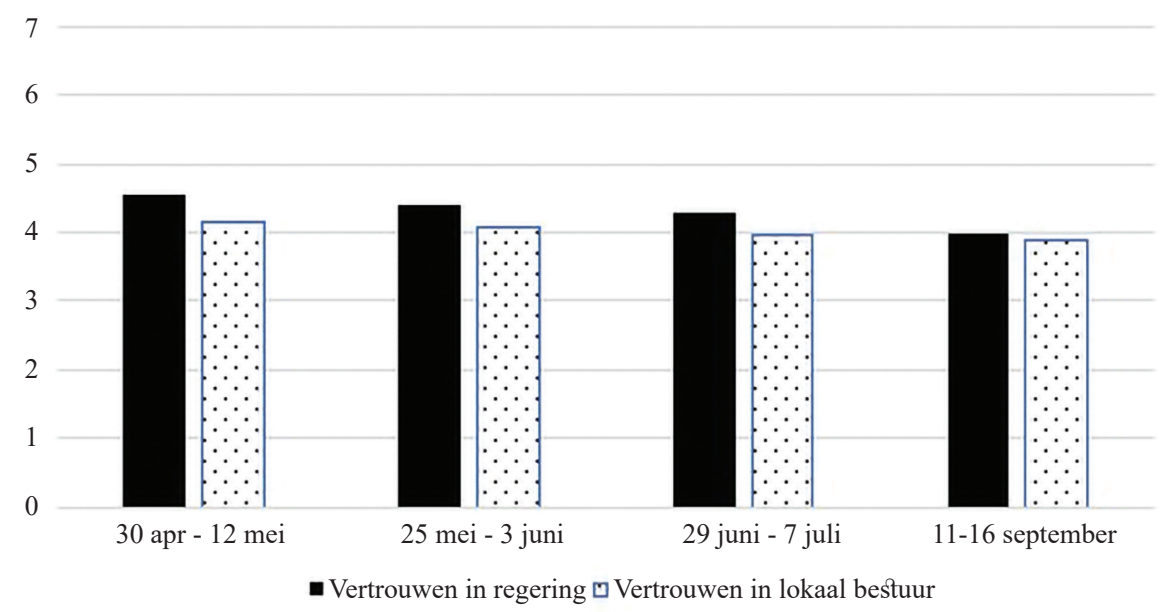

Figuur 2 Politiek vertrouwen. De y-as geeft vertrouwen in de politiek weer op een schaal van 1 (helemaal geen vertrouwen) tot 7 (veel vertrouwen).

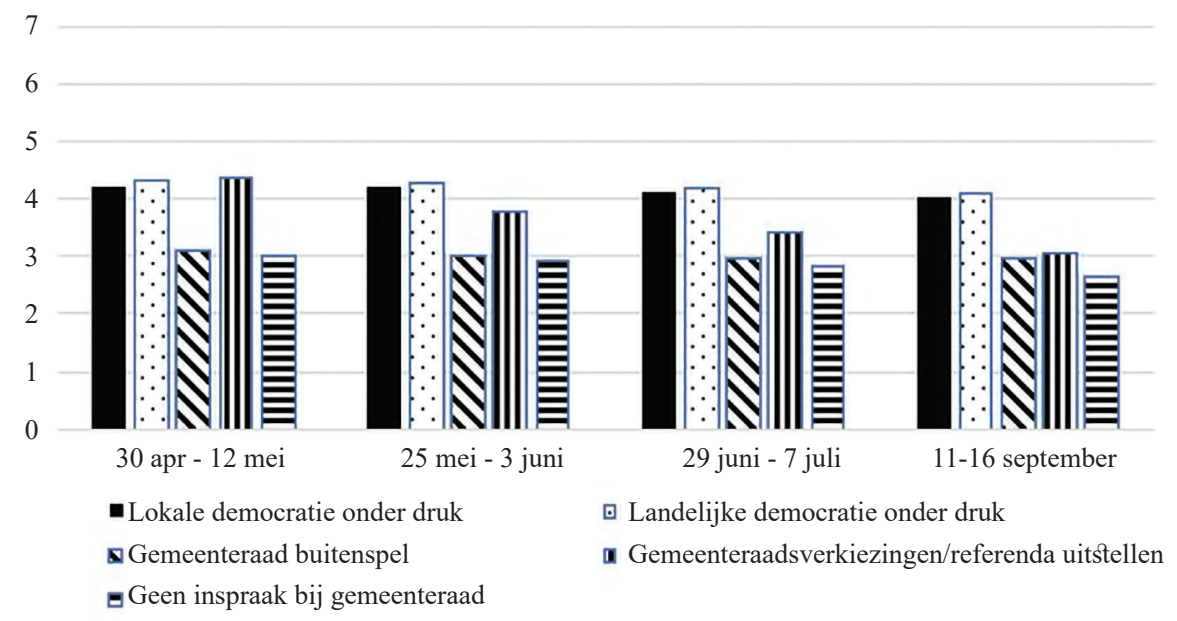

Figuur 3 Democratische attitudes en percepties. De y-as geeft de mate waarin respondenten het eens zijn met de stelling op een schaal van 1 (helemaal mee oneens) tot 7 (helemaal mee eens).

Ten slotte kijken we naar verschillende vormen van participatie (figuur 4). Hier zien we dat deze, op het volgen van de persconferenties na, bijzonder laag is. Op een schaal van 0 tot 4 blijven de scores voor het volgen van Tweede Kamerdebatten steken rond ,5, en voor gemeenteraadsdebatten komen ze nauwelijks boven de 0 uit. Gezien deze lage scores en beperkte variatie gebruiken we deze variabelen verder niet in de verklarende modellen. 
Samenvattend: het mediagebruik veranderde gedurende de eerste golf van de coronacrisis. Ook politiek vertrouwen en de perceptie dat de democratie onder druk staat veranderden gedurende de eerste golf. Maar deze beschrijvende statistieken geven geen antwoord op de vraag in hoeverre verschuivingen in de informatievoorziening tijdens Covid-19 samenhangen met het vertrouwen in de lokale/nationale overheid. Ook geven ze geen antwoord op de vraag in hoeverre verschuivingen in de informatievoorziening tijdens Covid-19 samenhangen met het beeld van de democratische processen die onder druk staan. In de volgende sectie gaan we deze verwachtingen formeel testen.

\section{Effecten van mediagebruik op vertrouwen}

Onze eerste verklarende analyse richt zich op de effecten van mediagebruik op vertrouwen (zie tabel 1). Hierbij kijken we apart naar vertrouwen in de regering en vertrouwen in de lokale overheid. Hier zien we een duidelijk verschil tussen beide. Vertrouwen in de regering wordt sterker gedreven door mediagebruik dan vertrouwen in de lokale overheid. In beide gevallen draagt het kijken van de publieke omroep bij aan vertrouwen. Het effect van kijken naar de publieke omroep op vertrouwen lijkt iets sterker dan het effect dat kijken naar de publieke omroep heeft op vertrouwen in de lokale overheid. In het geval van de regering doet ook het kijken van commerciële televisie er (een beetje) toe: een hogere consumptie van commerciële televisie leidt tot meer politiek vertrouwen. Terwijl het kijken van meer commerciële televisie geen statistisch significant effect - het effect is zelfs negatief in plaats van positief - heeft op vertrouwen in de lokale democratie.

Het is ook niet onredelijk om te verwachten dat sociale media vertrouwen ondermijnen. In dat geval zouden we een negatief effect van gebruik van socialemediaconsumptie op vertrouwen moeten zien. In deze data vinden we geen bewijs voor deze verwachting. De coëfficiënten zijn positief in plaats van negatief en ze zijn niet statistisch significant. Tot slot vinden we geen bewijs dat andere media kranten en expertwebsites - een effect op politiek vertrouwen hebben.

Onze data bevatten ook andere achtergrondkenmerken van onze deelnemers. Het vertrouwen is hoger onder vrouwen, en het vertrouwen in de regering is ook hoger onder hoger opgeleiden. De negatieve coëfficiënten voor wave 4 en 5 geven aan dat het vertrouwen, zoals we ook al eerder zagen, terugloopt in de tijd van onze studie. Het vertrouwen in de regering is op individueel niveau stabieler (grotere invloed van t-1) en derhalve ook beter te verklaren (verklaarde variantie, 59 ten opzichte van ,24 voor de lokale overheid).

Voor percepties over de druk op democratische processen en de steun voor democratiebeperkende maatregelen blijkt mediagebruik er minder toe te doen; zie de resultaten in tabel 2. Alleen de consumptie van commerciële televisie vergroot de steun voor democratiebeperkende maatregelen. Andere media hebben geen significante invloed. We zien voor beide afhankelijke variabelen dat vrouwen hoger 
Tabel 1 Verklaring politiek vertrouwen

\begin{tabular}{lllll}
\hline & Regering & \multicolumn{2}{c}{ Lokale overheid } \\
& B & SE & B & SE \\
\hline Vertrouwen (t-I) & $0,73^{* * *}$ & 0,02 & $0,4 I^{* * *}$ & 0,03 \\
Leeftijdsgroep & 0,03 & 0,03 & 0,03 & 0,05 \\
Geslacht (V) & $0,10^{* *}$ & 0,03 & $0,17^{* *}$ & 0,06 \\
Opleidingsniveau & $0,1 I^{* * *}$ & 0,03 & 0,04 & 0,05 \\
Publieke tv & $0,08^{* * *}$ & 0,02 & $0,06 *$ & 0,03 \\
Commerciële tv & $0,04^{*}$ & 0,02 & $-0,01$ & 0,03 \\
Kranten & 0,02 & 0,02 & $-0,01$ & 0,04 \\
Sociale media & 0,01 & 0,02 & 0,04 & 0,03 \\
Expertsites & 0,03 & 0,02 & 0,02 & 0,04 \\
Wave 4 & $-0,06$ & 0,05 & $-0,07$ & 0,07 \\
Wave 5 & $-0,28^{* * *}$ & 0,04 & $-0,15^{*}$ & 0,07 \\
Constant & $0,5 I^{* * *}$ & 0,12 & $1,83^{* * *}$ & 0,21 \\
Verklaarde variantie &, 59 &, 24 & & \\
\hline
\end{tabular}

$* \mathrm{p}<0,05 ; * * \mathrm{p}<0,01 ; * * * \mathrm{p}<0,00 \mathrm{I} ; \mathrm{N}=3,234$.

\section{Tabel 2 Verklaring politieke percepties en attitudes}

\begin{tabular}{lllll}
\hline & \multicolumn{3}{l}{ Processen onder druk } & \multicolumn{2}{l}{ Maatregelen } \\
& B & SE & B & SE \\
\hline Afhankelijke variabele (t- I) & $0,46^{* * *}$ & 0,02 & $0,50^{* * *}$ & 0,02 \\
Leeftijdsgroep & 0,00 & 0,04 & 0,03 & 0,03 \\
Geslacht (V) & $0,09^{*}$ & 0,05 & $0,13^{* *}$ & 0,04 \\
Opleidingsniveau & $-0,12^{* * *}$ & 0,04 & $-0,08^{* *}$ & 0,03 \\
Publieke tv & $-0,01$ & 0,02 & $-0,03$ & 0,02 \\
Commerciële tv & 0,03 & 0,03 & $0,07^{* * *}$ & 0,02 \\
Kranten & 0,02 & 0,03 & $-0,05$ & 0,03 \\
Sociale media & $-0,04$ & 0,02 & 0,00 & 0,02 \\
Expertsites & $-0,05$ & 0,03 & 0,04 & 0,03 \\
Wave 4 & $-0,05$ & 0,06 & $-0,02$ & 0,05 \\
Wave 5 & $-0,11$ & 0,06 & $-0,12^{* *}$ & 0,05 \\
Constant & $1,94^{* * *}$ & 0,17 & $0,90^{* * *}$ & 0,13 \\
Verklaarde variantie &, 22 &, 32 & & \\
\hline
\end{tabular}

$* \mathrm{p}<0,05 ; * * \mathrm{p}<0,0 \mathrm{I} ;$ *** $^{\mathrm{p}}<0,00 \mathrm{I} ; \mathrm{N}=3,234$.

scoren, en hoger opgeleiden lager. Ten slotte zien we dat voor beide de scores door de tijd heen afnemen (negatieve coëfficiënten voor wave 4 en 5). 


\section{Conclusie}

Onze studie laat zien dat in de loop van de eerste golf van de coronacrisis het mediagebruik en vertrouwen in de politiek afnamen. Daarnaast is onder Nederlanders het gevoel dat de coronacrisis de nationale en lokale democratie onder druk zet duidelijk aanwezig. Deze gevoelens nemen gedurende de onderzoeksperiode maar zeer beperkt af. Ons doel was om te onderzoeken in hoeverre mediagebruik het vertrouwen in de politiek en opvattingen over de democratie beïnvloedt. We vinden dat kijken naar de publieke omroep een positief effect heeft op politiek vertrouwen. Tegelijk heeft mediagebruik maar een zeer beperkte invloed op de opvattingen over de democratie.

Uiteraard zou het goed zijn om het mediagebruik in meer detail te onderzoeken. Een logische vervolgvraag zou natuurlijk zijn of en in welke mate de inhoud of toon van de berichtgeving een effect heeft op politiek vertrouwen en de percepties over democratische processen. De huidige studie heeft niet de mogelijkheid om dit te testen. Hiervoor zou de inhoud van de programma's gedurende de dataverzameling gecodeerd moeten worden. Je zou bijvoorbeeld kunnen verwachten dat naarmate de toon negatiever is, er misschien minder vertrouwen ontstaat. Ook zou de aanwezigheid van zogenaamde 'blame frame', waarbij een duidelijke schuldige wordt aangewezen, een negatief effect op vertrouwen in de politiek kan hebben. Dit zijn maar enkele voorbeelden van wat er gedaan kan worden wanneer de inhoud wordt gekoppeld aan deze data.

Nederlanders zijn over het algemeen niet heel erg bereid om democratische rechten zoals stemmen op te geven voor het bestrijden van het coronavirus (zie figuur 3), maar uiteraard zit er spreiding rondom het gemiddelde. Het is belangrijk om te onderzoeken wie meer of minder geneigd is om de democratie te steunen. Vergelijkend onderzoek - vóór de pandemie - laat zien dat vooral mensen met rechts-conservatieve opvattingen zich uitspreken voor antidemocratische politici (Malka e.a., 2020). Zijn het de rechts-conservatieve kiezers die onder aanvoering meer geneigd zijn om de democratische rechten in te ruilen?

Op het moment van schrijven (januari 2021) verkeert Nederland volop in de tweede golf. Juist in deze periode staan onderwerpen zoals politiek vertrouwen en perceptie van democratische processen centraal in de publieke discussie. Tegelijk zien we ook een stevig debat over de rol van mis- en disinformatie over de pandemie, al dan niet vergroot door zowel traditionele als sociale media. De vraagstukken die in onze paper centraal staan, zullen alleen maar belangrijker worden in de aanloop naar de Tweede Kamerverkiezingen van 2021 en het vervolg van deze pandemie.

\section{Literatuur}

Alsan, M., Braghieri, L., Eichmeyer, S., Kim, M.J., Stantcheva, S., \& Yang, D.Y. (2020). Civil Liberties in Times of Crisis (nr. w27972). National Bureau of Economic Research. 
Arceneaux, K., Bakker, B.N., Hobolt, S., \& Vries, C.E. de (2020). Is COVID-19 a Threat to Liberal Democracy?https://psyarxiv.com/8e4pa/ .

Baekgaard, M., Christensen, J., Madsen, J.K., \& Mikkelsen, K.S. (2020). Rallying around the flag in times of COVID-19: Societal lockdown and trust in democratic institutions. Journal of Behavioral Public Administration, 3 (2).

Bakker, B.N., Wal, A. van der, \& Vliegenthart, R. (2020). COVID-19 panel study in the Netherlands. https://doi.org/10.17605/OSF.IO/KWZ7A .

Bol, D., Giani, M., Blais, A., \& Loewen, P.J. (2020). The effect of COVID-19 lockdowns on political support: Some good news for democracy? European Journal of Political Research.

Giommoni, T., \& Loumeau, G. (2020). Lockdown and voting behaviour: A natural experiment on postponed elections during the COVID-19 pandemic. Te raadplegen via SSRN.

Jørgensen, F.J., Bor, A., Lindholt, M.F., \& Petersen, M.B. (2020). Lockdown Evaluations During the First Wave of the COVID-19 Pandemic .

Malka, A., Lelkes, Y., Bakker, B.N., \& Spivack, E. (2020). Who is Open to Authoritarian Governance within Western Democracies? Perspectives on Politics, 1-20.

Reeskens, T., Muis, Q., Sieben, I., Vandecasteele, L., Luijkx, R., \& Halman, L. (2020). Stability or change of public opinion and values during the coronavirus crisis? Exploring Dutch longitudinal panel data. European Societies, 1-19.

Trein, P. (2020). The Paradox of Prevention: Authoritarian Past and Liberal Democracy in Times of Crisis. Te raadplegen via SSRN: https://ssrn.com/abstract=3625523 of http:// dx.doi.org/10.2139/ssm.3625523

Vries, C.E. de, Bakker, B.N., Hobolt, S., \& Arceneaux, K. (2020). Crisis Signaling: How Italy's Coronavirus Lockdown Affected Incumbent Support in Other European Countries. Political Science Research \& Methods. 